\title{
COMPETITIVE STRATEGY FOR HOUSING SECTOR USING SWOT AND ANALYTICAL HIERARCHY PROCESS: A CASE STUDY OF ROYALE SAWANGAN RESIDENCE
}

\author{
Tjahjono Hendro* \\ School of Business, IPB University, Bogor, Indonesia \\ Simanjuntak Megawati, Yuliati Lilik Noor \\ Department of Family and Consumer Sciences, Faculty of Human Ecology, IPB University, \\ Bogor, Indonesia, \\ *E-mail: hendro sbipb@yahoo.com
}

\begin{abstract}
The research aimed to analyze the internal and external aspects of the environment of Royale Sawangan Residence. The extensive research was also to formulate the Competitive Strategy of Royale Sawangan Residence in the future. This research applied the qualitative approach with a descriptive type of research and using SWOT (Strength, Weakness, Opportunity, Threat) analysis, and AHP (Analytical Hierarchy Process). Property business run by Royale Sawangan Residence had the total internal score (IFE) of 3.64 which indicated that the company's ability to respond to the strengths and weaknesses and the total external score (EFE) was 3.14 which indicated that the external position of the property business was above average. Therefore, it could be mapped from both matrixes IE (Internal External). IE matrix that was in the position of the cell I (grow and build). Result SWOT for the internal and external factors of Royale Sawangan Residence, concluded that the SO (StrengthOpportunity) are the recommended alternatives strategy to maximize the strength point and foreseen opportunities. Then, the result from the strategic formulation using SWOT analysis selected using AHP. The alternative strategy recommended to Royale Sawangan Residence is to build a small house, infrastructure development, redesigning the house, promotion and joint event exhibition, cooperation with several contractors, and had a dynamic marketing program. By applied these alternative strategies, the Royale Sawangan Residence can run its competitiveness optimally by determining this strategic priority in the implementation.
\end{abstract}

\section{KEY WORDS}

Competitive strategy, SWOT analysis, residence, internal factors, external factors.

Housing needs increase every year, along with population growth. Problems arise when an adequate housing supply does not accompany population growth. Limited land is one of the inhibiting factors for housing developers to build housing in the city center. The more strategic location of housing will provide ease of selling homes. Another factor that is also a consideration for prospective buyers to choose a home is the distance of the location of housing and where it works to provide convenience in its activities.

For housing developers, population growth is undoubtedly an attractive business prospect. Location, price, design, marketing, and banking support must be a concern. In this business must also consider other developers who also capture this business opportunity. It is the developer who has the right competitive strategy that will succeed in this business.

The supply of houses has not matched increased population growth either due to birth factors or due to urbanization from villages to cities. One limiting factor is the limited land for housing development in a city center such as Jakarta. The developers offer 2 (two) first housing model concepts with vertical concepts such as building a low-rise apartment and apartment to anticipate existing land limitations and lent house concept housing footprint).

Royale Sawangan Residence located on Jalan Raya Sawangan Cinangka Depok is one of the houses built with the concept of a lent house, and the location is not too far from the city center. Since it began to be marketed in 2015 until now, the number of units sold is 
as many as 50 units out of the total 173 units available. This is a problem because the number of lots sold does not reach the sales target of 40-50 housing units each year.

Devi's research (2012) on Competing Strategies of Rusunami Kalibata examines how vertical concept houses become the trend of choice in choosing the house in big cities. Limited land is the main factor that is the reason for developers to offer this concept. When comparing the concept of a house tread (lent house) and the vertical concept, each has advantages and disadvantages. The location factor which is close to the place of work becomes a consideration for consumers to buy a vertical house in the middle of the city.

The difference between this research analyses of the competitive business strategy of the housing business with previous research is because it analysed the factors that influence the lent house business. When compared with the concept of vertical houses and lent houses, there are differences in characteristics between the two. However, there are still the same factors as strategic location as one essential factor.

This research is interested in exploring every aspect and information from both internal and external Royale Sawangan Residence. Researchers analyze using SWOT then combine with AHP to find the right strategy and can be a suggestion for this housing project. From the initial survey, the researchers found the following problems:

1. The pattern of house construction;

2. Design and type of house;

3. How to set selling prices and estimate price increases each year;

4. Business and marketing strategies;

5. Human resources Marketing Division;

6. Threats from competitors around residential locations.

The objectives of this study are (1) Analyzing internal and external factors that influence competitive strategies using SWOT and AHP Analysis in Royale Sawangan Residence, and (2) Formulating appropriate competitive strategies for Royale Sawangan Residence.

\section{LITERATURE REVIEW}

According to Afuah (2004), business is an organized effort of individuals in producing and selling for a profit, the goods and services that satisfy society's needs. The general term business refers to all such efforts within a society or within an industry. Furthermore, the strategy, according to Prahalad and Hamel (1997), is an incremental action and continuous and is carried out based on the perspective of what is expected by customers in the future. Thus strategic planning almost always starts with "what can happen."

According to Hanson and Dowling (2008), in general, the external environment can be grouped into 3 (three) groups that are interconnected with one another, namely the general environment, industrial environment, and competitor environment. According to Campbell, Stonehouse, and Houston (2002), the internal analysis provides an understanding of the potential advantages of existing competitiveness, and which areas should be prioritized to ensure business continuity.

Hanifah's research (2016) entitled Analysis of Telkomsel's Business Strategy in Facing Competition. This research used SWOT with IFE and EFE to analyze the company's internal and external environment. In this research, what we want to know is whether the business strategy used by Telkomsel is right in the face of competition. The results of this study from the analysis of internal and external factors along with the Grand Strategy matrix found that the Telkomsel Strategy is a Rapid Growth Strategy where Telkomsel can improve its competitive position. The SWOT analysis results obtained that Telkomsel has carried out the right strategy. Another thing is the consideration of internal and external factors. Telkomsel can expand its network to remote areas and must continue to innovate while still paying attention to the quality of service to its customers

Wulandari conducted research (2009) entitled The Strategy for Developing Small Commodity-Based Small Industrial Zones (Case Study of the Industrial Center for Chips in Bandar Lampung City). This research used a case study method with a quantitative 
approach that combines qualitative and quantitative data inputs as well. SWOT analysis with IFE (Internal Factor Evaluation) to analyze the internal environment and EFE (external factor evaluation) is used to analyze the company's external factors. AHP analysis in choosing several alternative strategies obtained from the SWOT analysis.

Mutia's research (2017) on Analysis of Competitive Strategy of PT Pertamina Lubricants in the MEA Era Domestic Market. This research is a descriptive qualitative study by conducting interviews with internal parties at PT. Pertamina Lubricants is top management and external parties, namely users of lubricants both for cars and motorcycles. The analysis of this study used the SWOT method, five forces analysis, and the value chain competitive strategy. The results of the research analysis showed that the competitive value chain strategy that must be maintained by PT. Pertamina Lubricants is differentiation. Companies must also be more careful of the threat of new arrivals, and focus more on approaching customers, prioritizing the best quality and price provided. Besides, the company pays more attention to the needs of customers providing a variety of products following the specifications of machines owned by customers.

Mardiyanto's research (2014) on Analysis of the "Green Building" Strategy as a Competitive Advantage of Corporations in Competing in the Construction Industry (Case Study at PT PP Persero). PT PP (Persero) Tbk is one of the national construction service companies that have four business sectors, namely: Regular construction (buildings, ports, bridges, roads), EPC (Engineering, Procurement, Construction), Property and Investment.

The research of Handayani (2015) titled Competitive Strategy Analysis at BRI Syariah Branch Purwokerto. This study applied a qualitative study using descriptive qualitative, namely collecting techniques in the form of observation, documentation from various sources, especially the Financial Services Authority, BRI Syariah Annual Report, and through the BRI Syariah official website. Then there are interviews to find out more about the strategies used. Data analysis uses a competitive advantage analysis strategy from Michael Porter, namely Analysis of 5 Competitive Advantages, Generic Competitive Analysis of low cost, differentiation and focus, and SWOT to read strengths, weaknesses, opportunities, and threats. The advantages of BRI Syariah Purwokerto Branch at present are the extensive network, the support of the head office and the main office, in-depth knowledge of the managed market share, namely the middle to lower. The primary improvement that should be done is the management of human resources that can face competition and a more in-depth approach to the community in disseminating Islamic banking products and services.

Pahlevi (2012) conducted research entitled Competitive Strategy Analysis Using the Constraint Management Method Approach Case Study at PT Astra Honda Motor. The study took a Constraint Management method approach to be able to identify problems and see whether there is a relationship between the problems that occur. Constraint Management is a method based on the Theory of Constraint that aims to control the constraints that are happening in a system.

\section{METHODS OF RESEARCH}

This research was conducted at Royale Sawangan Residence located on Jl. Raya Cinangka no. 31 Serua, Bojongsari, Depok City, West Java. This housing estate is located on the edge of the border city between Depok City, South Tangerang, and Jakarta. Researchers are interested in knowing the business strategies used to face competition with some of the surrounding housing.

This research used primary and secondary data. Primary data were provided from the Focus Group Discussion (FDG) and in-depth interviews. Focus Group Discussion (FDG) is conducted to parties from both internal and external companies, including Project Managers, Financial Consultants, Property Consultants, Consultants for Public Appraisal Services and in-depth interviews with ten families of Housing Residents. Whereas secondary data were obtained from literature, journals, previous research, books, internet and related institutions such as BPS, Ministry of Public Works and Public Housing and Bank Indonesia. 
The technique of taking respondents in this study was done by purposive sampling, namely the determination of respondents with specific considerations suitable for use in research. Therefore, respondents are key informants who know the most information needed in this study. Respondents were selected based on their respective capacities/expertise both within the company, including the owner/project manager, and from external companies including financial consultants, property consultants, public appraisal services consultants, government and residents of housing.

Data collection applied in-depth interviews with resource persons who have competence in research. Focus Discussion Group (FDG) was conducted with several speakers, namely company employees as many as 3 (three) internal parties and 2 (two) people from external namely 1 ( one) financial consultant and 1 (one) property consultant.

To strengthen the analysis of competitive strategies in Royale, Sawangan Housing researchers used SWOT analysis (David 2009) and Analytical Hierarchy Process (AHP). The function of the SWOT analysis in this study aims to get opinions or opinions from experts after identifying internal and external factors in Royale Sawangan Residence. According to Dess et al. (2009), SWOT analysis is a strategic planning instrument that is used to evaluate the Strengths, Weakness, Opportunities, and Threats that are contained in a project or business. This process involves setting specific goals from business or project speculation and the process of identifying internal and external factors that support or do not support the achievement of company goals.

To choose an alternative strategy used by the company used AHP analysis. According to Saaty (1993), the Analytical Hierarchy Process (AHP) is a method for solving an unstructured, complicated situation into several components in a hierarchical arrangement, by giving subjective values about the relative importance of each variable and determining which variable has the highest priority to influence results in that situation.

\section{RESULTS AND DISCUSSION}

SWOT Analysis. Table 1 shows the internal factors that are strengths and weaknesses of Royale Sawangan Residence, while in Table 2, the external factors present as Opportunities and Threats are presented.

Table 1 - Internal Factors

\begin{tabular}{|l|c|}
\hline \multicolumn{1}{|c|}{ Strength } & Weakness \\
\hline Strategic location & \\
\cline { 1 - 1 } Capital & Project operational activities \\
Company name & Promotion and Marketing \\
\cline { 1 - 1 } Property experience & \\
\hline Human Relationship & \\
\hline
\end{tabular}

Table 2 - External Factors

\begin{tabular}{|l|l|}
\hline \multicolumn{1}{|c|}{ Opportunity } & \multicolumn{1}{c|}{ Threats } \\
\hline 1. One million house program & 1. Government regulations \\
\cline { 1 - 1 } 2. Population density & 2. Dependence on contractors \\
\cline { 1 - 1 } 3. The need for housing in strategic locations & \\
\cline { 1 - 1 } 4. Development of the Property Business & \\
\cline { 1 - 1 } 5. Decreasing interest rates &
\end{tabular}

IE Matrix Merging Stage. Combining the IE matrix is a matrix that combines the score weights on the IFE matrix and the EFE matrix so that it can know the position of the company's existence and can know what strategies should be carried out by Royale Sawangan Residence Management.

The IE matrix is based on two dimensions, where the total score of IFE weights on the $x$-axis and the total score of EFE weights on the $y$-axis. Each division in an organization or company must make an IFE matrix and EFE matrix. After the final scores from the IFE matrix and EFE matrix are obtained, the next step is to enter these values into the External Internal 
matrix to determine the company's position. From the IE matrix calculation, the weight is 3.64, and the EFE matrix has obtained the weight 3.14 so that the results of the IE matrix mapping can be seen in Figure 1.

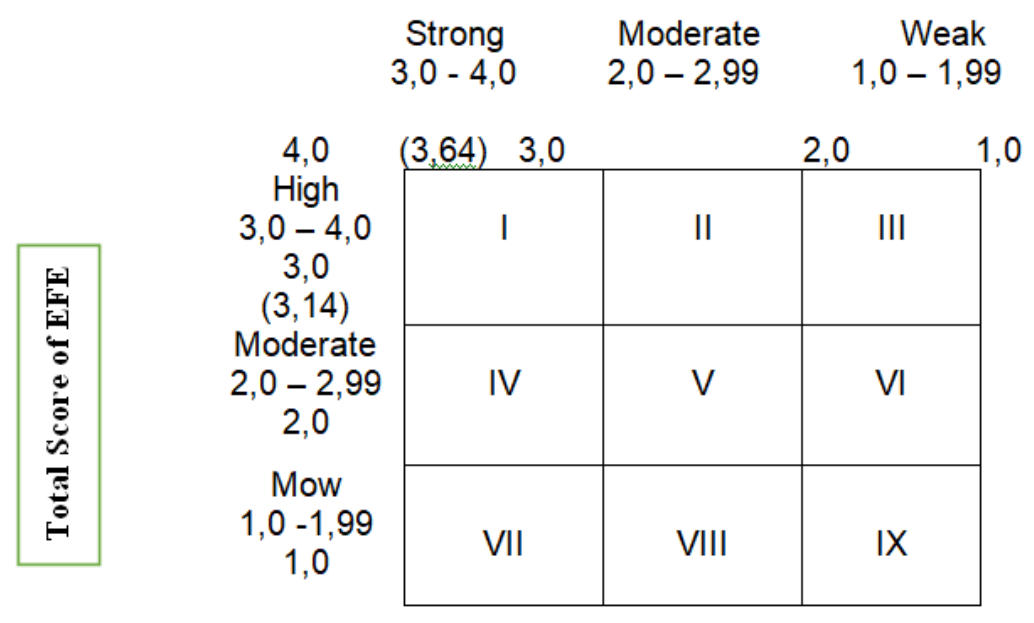

Figure 1 - Merging Internal - External Matrices

SWOT Matrix Results. Based on Table 3, six strategies can be formulated from a combination of internal and external factors. These six strategies are divided into four strategy groups, as follows:

1. Strategy S-O (Strengths-Opportunities).

This strategy is a combination of strengths and weaknesses where the company uses its strengths to take advantage of opportunities that consist of: a. Construction of a minimalist one-storey design house; b. Development of public facilities and infrastructure following the initial plan of the project; c. Redesign of house types and shophouses.

2. W-O (Weakness-Opportunities) Strategy.

This strategy is a combination of weaknesses and opportunities, which aims to minimize or correct weaknesses by taking advantage of opportunities, and consists of property promotion and marketing

3. S-T (Strength-Threat) Strategy.

This strategy was created using the power of Royale Sawangan Residence to avoid, or overcome threats that include the company cooperates with several contractors and management of building material stock management

4. W-T (Weakness-Threat) Strategy.

This strategy was created to minimize weaknesses and avoid threats that consist of dynamic marketing strategy to anticipate regulatory changes.

Some strategies based on Table 3 may not all be implemented simultaneously. Priority scale should be arranged if it will be carried out together. Resource limitations must also be considered. Determination of the strategic priority scale of the Strength-Opportunity (SO) policy generated through SWOT analysis is further processed using the Analytic Hierarchy Process (AHP).

AHP Analysis. Based on previous the SWOT analysis, it obtained several alternative competitive strategies. Nevertheless, because of the limited resources available, selected competitive strategies may not be done simultaneously or simultaneously. To overcome this, the process of determining the priority of competitive strategy is needed from the alternatives based on the criteria approach, namely, generic strategy. Which competitive strategy is ultimately considered more critical for achieving company goals. The hierarchy structure of the Port and Dredging Company Pension housing business strategy is presented in Figure 2.

Managerial Implications. Every business has competition. Royale Sawangan Residence must look for strategies and innovations to face competition that focuses on the SO Strategy (strength opportunity). Royale Sawangan Residence has internal factors that are good enough to deal with competition, such as location and substantial capital. 
Table 3 - IFE, EFE, and SWOT Interaction Matrix

\begin{tabular}{|c|c|c|}
\hline Factors & Strength (S) & Weakness (W) \\
\hline EFE & $\begin{array}{l}\text { 1. Strategic location } \\
\text { 2. Strong capital } \\
\text { 3. Company Name } \\
\text { 4. Experience in property } \\
\text { 5. Reliable HR }\end{array}$ & $\begin{array}{l}\text { 1. Project Operational Activities. } \\
\text { 2. Promotion and Marketing. }\end{array}$ \\
\hline Opportunity $(\mathrm{O})$ & Strategy SO & Strategy WO \\
\hline $\begin{array}{l}\text { 1. One Million Homes Program } \\
\text { 2. Jakarta Population Density } \\
\text { 3. Strategic Residential Needs } \\
\text { 4. Development of the Property } \\
\text { Business in Indonesia } \\
\text { 5. Bank Indonesia Interest Rates } \\
\text { 6. Support of Banking Institutions }\end{array}$ & $\begin{array}{l}\text { 1. Construction of a minimalist one- } \\
\text { storey design house. (S1, S2, S3, } \\
\mathrm{S} 4, \mathrm{O} 1, \mathrm{O} 3, \mathrm{O} 4) \\
\text { 2. Construction of public facilities } \\
\text { according to the initial plan of the } \\
\text { project. (S1, S2, S3, O3, O4) } \\
\text { 3. Redesign of house types and } \\
\text { shophouses. (S1, S2, O4) }\end{array}$ & $\begin{array}{l}\text { Property Promotion and } \\
\text { Marketing. (W2, O1, O4, O5, } \\
\text { O6) }\end{array}$ \\
\hline Threat $(\mathrm{T})$ & ST Strategy & WT Strategy \\
\hline $\begin{array}{l}\text { 1. Changing Government Regulation } \\
\text { 2. Company Dependence on } \\
\text { Contractors } \\
\text { 3. Building Material Price Fluctuations }\end{array}$ & $\begin{array}{l}\text { Collaboration with several } \\
\text { contractors and Management of } \\
\text { building material stock } \\
\text { management (S2, S4, T2, T3) }\end{array}$ & $\begin{array}{l}\text { Dynamic marketing strategies to } \\
\text { anticipate regulatory changes. } \\
(\mathrm{W} 2, \mathrm{~T} 1)\end{array}$ \\
\hline
\end{tabular}

Goal

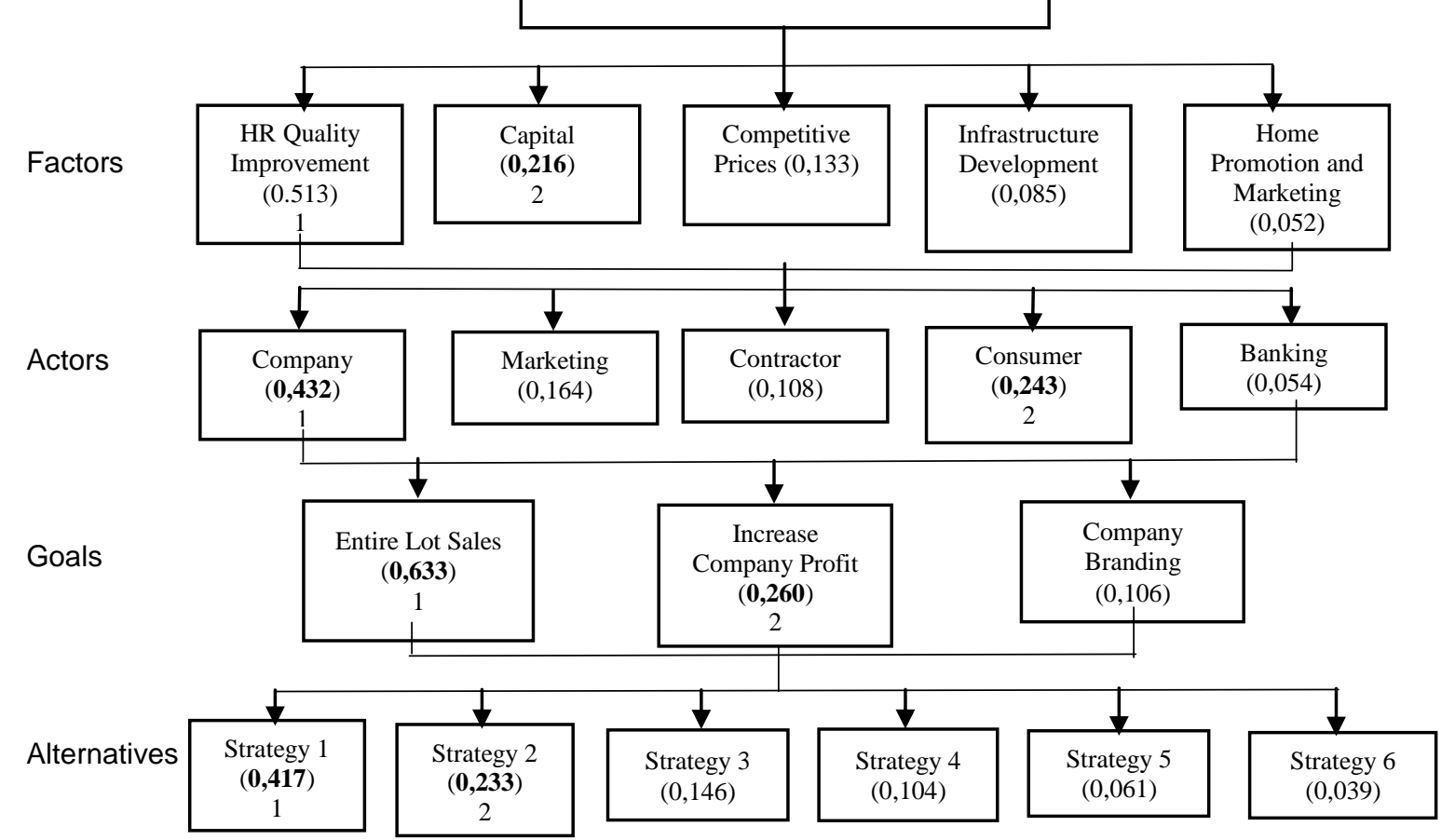

Figure 2 - Hierarchical Structure of the Housing Business

Table 4 - Weight and Priority Alternative Strategies for Goal

\begin{tabular}{|l|c|c|}
\hline \multicolumn{1}{|c|}{ Alternative Strategies } & Weight & Priority \\
\hline 1. Construction of a minimalist one-story house & 0,417 & 1 \\
\hline 2. Construction of fasum according to initial plan & 0,233 & 2 \\
\hline 3. Redesign of house types and shop houses & 0,146 & 3 \\
\hline 4. Property promotion and exhibition & 0,104 & 4 \\
\hline 5. Cooperation with several contractors and material stock management & 0,061 & 5 \\
\hline 6. Dynamic marketing strategies to anticipate regulatory changes & 0,039 & 6 \\
\hline
\end{tabular}


On the other hand, many opportunities have not been maximally utilized. The managerial implications of the strategy and its management innovation from the internal and external sides will be discussed as follows.

From the internal side (strength):

1. Efficient in the process of building a house. The company buys materials in large quantities to get lower prices so that the COGS of the house can be more efficient. The goal is that management can set lower home prices than competitors. This will significantly help attract the attention of potential customers by not reducing the quality of building materials.

2. Design and Type of House. Management should not build a 2 (two) storey house in order to sell the house at a competitive price. Homes for 2 (two) floors are slower for sale due to high prices. Management must redesign the previous house design and focus on building 1 (one) storey house because it can reduce the cost of production of the house.

3. To anticipate the demand for 2 (two) storey houses from consumers, Management can provide a particular block for potential customers who want to buy a type 2 (two) floor house.

4. The Layout Pattern of House Construction must be considered. Focus on building a house in the back of the block first. Before this, consumers were given too much freedom to choose the location of the block of houses they wanted to buy but had an impact on housing disorganization.

5. The front lots of houses are marketed after the back lots have been sold. Management can seek higher profits from home sales in the front due to higher prices.

6. Simple customization options when building a house, such as the selection of flexible wall paint colors according to the wishes of consumers. On average, housing management still does a little so that, hopefully, it can become an attraction for consumers.

7. Completing the initial plans for public facilities that have not yet been implemented. This will provide comfort for the existing residents so that it does not become a negative impact chain of communication with other parties such as potential customers.

8. Building a shop complex that can be used for businesses such as mini markets, snack centers, health clinics, and other facilities. In order to turn on the atmosphere of housing and help residents to meet their needs.

9. Management must improve the quality of its sales division HR by actively providing sales training and customer satisfaction.

From the External Side (Opportunity), the strategy is marketing and sales innovation. It needed to open more both exhibitions at the center of the crowd, active marketing on social media and distribution of promotional messages via targeted SMS blasting. Because so far, Royale Sawangan Residence Sales Division still relies too much on customer walk-ins.

\section{CONCLUSION AND SUGGESTIONS}

From the identification of internal factors, strength factors are obtained, namely, strategic location, substantial capital, company name, business experience in property and human resources (HR). The weakness factor is the surrounding environment and operational activities. Whereas from external factors obtained opportunity factors, namely the one million house program, population density, housing needs, reduction in prime lending rate and mortgage support from banks. The factors of weakness (threats) are changing government regulations, dependence on contractors and fluctuations in material prices. From the SWOT analysis of internal and external factors, a Strength-Opportunity (SO) competitive strategy is obtained, which means that management must utilize and maximize the potential of existing internal forces and take advantage of all the potential that exists in the company's external. In the AHP analysis, it is concluded that the the alternative strategy recommended to Royale Sawangan Residence is to build a small house, infrastructure development, redesigning the house, promotion and joint event exhibition, cooperation with several contractors, and had a dynamic marketing program. By applied these alternative strategies, the Royale Sawangan Residence can run its competitiveness optimally by determining this strategic priority in the implementation. 
From the Royale Sawangan Residence location, there is still much research that can be done. In addition to Competing Strategies, other research that can be done is from the analysis of Consumer Behavior Analysis in deciding to buy a house, Analysis of Housing Business Marketing Strategy and Analysis of Housing Business Customer Satisfaction.

The researcher's suggestion for the development of Royale Sawangan Residence is to conduct 1 or 2 other studies that can complement this research of competitive strategy analysis. Royale Sawangan Residence has not been in business for several months. Royale Sawangan Residence must conduct several business activities with a different strategy from the previous strategy. This strategy requires time, preparation and careful calculation. Factors that can be obstacles must be anticipated and factors that become strengths must be used as the foundation of the strategy. Management must be sensitive to look for and read every opportunity that exists. From the internal side such as capital, human resources, contractors (business partners) and materials must be calculated as efficiently and effectively as possible. Job targets in each division must be considered. In terms of human resources, the marketing department must be recruited from candidates who have the capacity and ability in the property sector.

\section{REFERENCES}

1. Afuah, A. 2004. Business Model: A Strategic Management Approach. McGraw-Hill: New York.

2. Campbell, D. J., Stonehouse, G., \& Houston, B. 2002. Business strategy: an introduction (2nd Ed.), Oxford, UK: Butterworth-Heinemann.

3. David FR. 2009. Strategic Management Concepts. Issue 12. Jakarta: Four Salemba. Jakarta.

4. Devi. 2012. Analysis of Ralibami Kalibata City Competitive Strategy. (Case Study of Rusunawa Kalibata City [Thesis]. West Java (ID): University of Indonesia.

5. Dess, G., Lumpkin, G., Eisner, G.T, \& Alan, B. 2009. Strategic Management of Text \& Cases, 5th edition, Irwin Professional Publisher.

6. Prahalad, C.K. \& G. Hamel, G. 1997. The Core Competence of the corporation. Oxford University Press.

7. Handayani 2015. Competitive Strategy Analysis at BRI Syariah Purwokerto Branch [thesis]. Yogyakarta (ID): Gadjah Mada University.

8. Hanifah. 2016. Analysis of Telkomsel's Business Strategy in Facing Competition. Lampung (ID): Lampung University.

9. Hanson, D., \& Dowling, P.J. 2008. Strategic Management, Thomson, South Melbourne, Australia.

10. Mardiyanto. 2014. Analysis of Green Building Strategies as a Corporate Competitive Advantage in Competing in the Construction Industry [thesis]. Yogyakarta (ID): Gadjah Mada University.

11. Mutia. 2017. Analysis of PT Pertamina Lubricants Competitive Strategy in the MEA Era Domestic Market [thesis]. Yogyakarta (ID): Gadjah Mada University.

12. Nofrizal. 2015. Competitive Strategy Analysis of Yogyakarta Digital Warehouse in Expanding the Market. Faculty of Economics, Lancang Kuning University. Journal of Scientific Economics and Business 12 (2) 247-261.

13. Pahlavi. 2014. Analysis of Green Building Strategies as a Corporate Competitive Advantage in Competing in the Construction Industry [thesis]. Yogyakarta (ID): Gadjah Mada University.

14. Saaty, T.L. 1993. Decision Making for Leaders, Analytic Hierarchy Process for Decision Making in Complex Situations. Jakarta: PT. Binaman Pressindo Library.

15. Wulandari. 2009. Strategy for Developing Commodity-Based Small Industrial Estates [thesis]. West Java (ID): University of Indonesia. 